\title{
Creativity in Collaborative Learning across the Life Span
}

\author{
Margarida Romero ${ }^{1,2}$, Pirkko Hyvönen ${ }^{3}$, Elena Barberà ${ }^{1}$ \\ ${ }^{1}$ Elearn Center, Universitat Oberta de Catalunya, Barcelona, Spain \\ ${ }^{2}$ ESADE Universitat Ramon Llull, Barcelona, Spain \\ ${ }^{3}$ University of Oulu, Oulu, Finland \\ Email: margarida@uoc.edu
}

Received June $6^{\text {th }}$, 2012; revised July $11^{\text {th }}$, 2012; accepted July $21^{\text {st }}$, 2012

\begin{abstract}
Creativity is one of the competencies required in order successfully to meet challenges across the life span. After defining the broad concept of creativity and its relevance in education, this paper discusses the outcome of a literature review on creativity in collaborative learning across the different stages of an individual's development, with a specific focus on the use of ICT as a means of fostering the creative learning process. Although much of the literature concerns creativity and critical thinking skills in children and adolescents, we analyze the specific requirements and specificities of these competencies in advanced adulthood. We aim specifically to characterize the capabilities of older adults to collaborate through Virtual Learning Environments (VLEs). The last part of the paper discusses means of promoting the development of creative skills at different ages, notably in elderly persons, and the use of collaborative learning technologies.
\end{abstract}

Keywords: Creativity; Collaboration; Collaborative Learning; ICT; Older Adults; Lifelong Learning

\section{Introduction}

People in today's society are living in constantly changing environments where they commonly confront complex and unexpected problems. Previously learned practices do not always provide adequate means of coping in these new situations. Creativity is required to deal with the evolution of new knowledge and technologies; hence, it is one of the skills we should develop across our life span (Hilton, 2008; Trilling \& Fadel, 2009). The traditional 3 Rs (Reading, wRiting, and aRithmetic) of the 20th century have been replaced by the 4Cs, namely Critical thinking and problem solving, Communication, Collaboration and Creativity and innovation skills (Frydenberg \& Andone, 2011). Creativity is considered a key competency for personal and social prosperity because "we live in the creative age of information, communication and collaboration” (Kampylis, Berki, \& Saariluoma, 2009: p. 15), in which technological advances in our daily lives demand continuous learning. According to Rojanapanich and Pimpa (2011), creativity can facilitate adaptation to globalisation and promote innovation.

As a human capability, creativity is considered to be a competence that can be learned and developed in a dynamic way across the life span, not only as an individual process but also as a collaboratively constructed one. A common misconception is that creativity is restricted to "artistic" subjects or belongs in domain of children and young people (see Straker \& Rawlinson, 2003) and that it as an individual outcome of an eccentric personality (Amabile, 1996). By contrast, we are interested in the collaborative creative process, not limited to the context of children and adolescents but extending throughout the whole span of age from the early years to the elderly. Creativity is nowadays understood as a social process, developed by transactions between persons sharing a context that can be supported by technology. "Creativity can be viewed as, and investigated as, one aspect of an ongoing dialogue in computer supported collaborative teams” (Sundholm, Artman, \& Ramberg, 2004: p. 101).

In this paper we aim to advance the understanding of the creative process in the elderly, focusing on the possibilities for fostering older adults' creative collaboration through supportive technologies. We start the study with an overview of the challenges faced by the elderly in their adoption of technologies, before defining the creative collaboration concept. Because of the lack of specific literature about creative collaboration across the life span, we review the research studies considering the evolution of creativity across the different life stages and the relationship between older adults and ICT. Finally, we synthesise the main findings and suggest future lines of research to advance understanding of creative collaboration across the life span.

\section{Adoption of Technology among the Elderly}

For older adults, as for many others, creativity is a prerequisite for using a computer, but it is also a consequence of using it (Hyvönen, 2002). In this section, we analyse the evolution of computer-based technologies in society and the challenges for older people of adopting these technologies.

Many public and private services have moved into digital solutions, forcing people to change to digital channels, whether they have experience of and interest in information and communication technology (ICT) or not. European inititiatives such the "European Year for Active Ageing" and the Action Plan on "Ageing Well in the Information Society" has highlighted the importance of older adults' access to ICT, active ageing and consequently the need to better understand their specific needs (Ala-Mutka, Punie, \& Redecker, 2008; Sourbati, 2009).

In the last fifteen years or so, computers and the Internet have proven themselves as empowering tools for older adults. They afford the sense of being an active citizen in the society. 
Older people use computers and the Internet for information, shopping, social interaction, banking and post their own writings through social media (Charness \& Holley, 2004; Galusha, 1998; Hyvönen, 2002; Selwyn, 2004; Sourbati, 2009; Vuori \& Holmlund-Rytkönen, 2005). Older users of computer technology are sometimes described as "silver surfers", who consider ageing as a positive phenomenon, who suffer little anxiety in their use of the technology and whose technical efficacy is high (Cody et al., 1999).

However, recent studies also point to a more negative experience among the elderly in their use of ICT, noting an exaggeration of positive emotions when interpreting older adults' computer use (Selwyn, 2004; Selwyn, Gorard, \& Furlong, 2005). Moreover, some older people cannot use computers and the Internet, nor do they want to (Hakkarainen \& Hyvönen, 2010; Hakkarainen, 2012). According to Selwyn, Gorard and Furlong (2005), there is a growing number of older adults who actively avoid using computers or have given up so doing. The reasons are many. Lack of confidence in their ability to master new technologies is one (Marquié, Jourdan-Boddaert, \& Huet, 2002). Another is what may be termed computer anxiety (Cody et al., 1999).

Wagner, Hassanein and Head (2010) cite many studies that indicate a correlation between older adults' use of computers and their well-being, owing to a decreasing in stress and loneliness. On the other hand, Hakkarainen and Hyvönen (2010) show that some older people find other things more important and creative than computers, such as hobbies (sports, reading, handicrafts, gardening and other nature activities). Indeed, they actively choose to live without computers in order to enhance their well-being. Thus, studies show contradictory causalities relating to the impacts of using computers in later life.

The problem, however, is that, in order to cope in today's and tomorrow's society, people need to use ICT to manage their daily affairs, such as banking and finance, as well as to keep in contact with other people.

\section{Supportive Technologies for Creative Collaboration across the Life Span}

This study considers the use of supportive technologies not only as a requirement but also as an opportunity to support creative collaboration among the elderly. It is developed in the context of the EU-funded Lifelong Learning Program and CoCreat project, which has the objective of enabling creative collaboration through supportive technologies. In the CoCreat project, one of the specific target populations is older adults in rural areas, where they may be forced to travel long distances to manage their everyday affairs. Along with regional changes, public services are increasingly becoming network-based; yet many elderly citizens can neither afford personal computers nor access possibilities to learn how to use them. The Internet has become a critical communication tool in rural areas, where neighbours, friends and relatives are living far apart (Malecki, 2003).

The CoCreat project aims to study how communication can be enhanced in rural areas and how public services can be brought closer to elderly people, promote active ageing by enhancing their access to new technologies for using public services, for pursuing hobbies for directly accessing local news and for social communication.

Fozard, Bouma, Franco and Bronswijk (2009: p. 192) high- light the importance of communication opportunities for the elderly: "[A]ll the virtual communication aids are available, ranging from e-mail to social networks, e.g., Facebook, dating services, and virtual chat room groups. At a more sophisticated level, video conferencing techniques are becoming more accessible to remotely connect members of a social group. One example was of a man, currently housebound because of a stroke, who kept in communication with friends in a local senior citizen group of which he was a member via a video link between the public area of the senior citizen center and his bedroom.”

Fozard, Bouma, Franco and Bronswijk (2009) argue the value of collaboration technologies as a support to enhance fun and creativity in the second half of life. According to Lambropoulos, Romero and Kommers (2011), technologies enable the creation of shared contexts for engagement of participants. Fun technologies are an opportunity for adults of all ages to engage in creative collaboration and interaction.

A preliminary case study has been developed in the first phase of the CoCreat project, aimed at analysing the impact of iPads as a supportive technology for creative collaboration among the elderly. The case study confirmed the creative potential of the elderly and equally the potential for tablets to overcome the challenges that elderly people experience in the adoption of ICT (Hyvönen, Romero, \& Barbera, 2012). In this study we first develop the concept of creative collaboration and, in the second part of the paper, conduct a systematic literature review on the creative collaboration process throughout the life span.

\section{Creative Collaboration: Definition}

Creative collaboration based on a collaborative tradition has not yet attracted much research interest. By contrast, collaboration in creativity has been studied widely. In our study, "creative" denotes the quality of collaboration, where the aim is to act together to find diverse ways to use technologies in order to enhance well-being and active ageing. The processes itself should free an individual's cognitive resources and provide something that they have not encountered or understood before, for instance social interaction, atmosphere or the exchange of ideas and feelings. Creativity is seen as an important part of collaboration and specifically of collaborative learning.

\section{Defining Collaboration}

By collaboration we do not refer only to a sense of belonging or cooperation, but rather to the co-construction of shared understanding (Roschelle \& Teasley, 1995). Computer-supported collaborative learning (CSCL) is the use of information and communication technology to enhance learning. The CSCL environment is not merely a means of supporting communication between people who are physically remote but a tool used in both co-presence and distance settings for shaping interaction in many ways and for capturing, analysing and mirroring these interactions in real time. It is important to realise that collaboration among participants can be designed. Dillenbourg, Järvelä and Fisher (2009) have defined eleven principles of CSCL, based on previous studies in the field (e.g. Dillenbourg, 2005; Dillenbourg, Baker, Blaye, \& O’Malley, 1996; Scardamalia \& Bereiter, 1994; Roschelle \& Teasley, 1995). Of these, seven are important in the context of older adults' use of ICT.

1) The focus is on social interaction rather than individuali- 
sation.

2) Cognition is seen primarily as a social process, in other words activities that foster social interaction are methods by which people construct knowledge.

3) The border between formal and informal is blurred, true especially in lifelong learning contexts, where informal learning plays a crucial part.

4) Collaborative learning does not take place just by getting people together. Under what conditions environments, technologies, design and interaction enhance learning is a crucial question.

5) Over-expectations of media effectiveness should be considered.

6) Effectiveness for learning should be addressed by considering efforts that individuals perform together: how shared understanding can be achieved.

7) In addition to virtual interaction, face-to-face interaction is needed.

Although these principles emphasize joint knowledge construction, shared understanding and social interaction, affective issues, emotions and motivation and their regulation should be taken into account as well (Dillenbourg, Järvelä, \& Fisher, 2009; Hadwin, Oshige, Gress, \& Winne, 2010; Järvelä, Volet, \& Järvenoja, 2005). For example, previous experiences of technologies may create frustration and negative estimations of the usefulness of ICT and an individual's competence (Capdeferro \& Romero, 2012).

\section{Defining Creativity}

Creativity refers to the generation of ideas that are original, valuable or useful (Sternberg \& Lubart, 1995). For years, creativity has been conceived as an individual trait, but also as a process and the product of the process (Amabile, 1996; Eysenck, 1995; Plucker, Beghetto, \& Dow, 2004; Romero \& Barberà, 2012; Runco, 2007). In this paper we consider creativity from a socio-cognitive viewpoint in terms of both an individual and a shared process. Creativity is not merely an original act or idea but also an accepted new solution that is collaboratively (co)constructed and shared by a group. The output of creativity may be an act that transcends the creator of the creativity (Sak \& Oz, 2010) and produces "changes in an existing domain, or transforms an existing domain into a new one [...] What counts is whether the novelty he or she produces is accepted for inclusion in the domain" (Csikszentmihalyi, 1997: p. 315). The importance of the usefulness of the ideas or acts that are considered creative is highlighted by Franken (1994: p. 396). This author considers "creativity as the tendency to generate or recognize ideas, alternatives, or possibilities that may be useful in solving problems, communicating with others, and entertaining ourselves and others". In other words, a "tendency to generate or recognize ideas, alternatives, or possibilities", otherwise known as divergent thinking, is strongly linked to creativity. As defined by Guilford $(1959,1962)$, creativity refers to processes to make the invisible visible, to generate novel associations and that encourage flexible ideation to generate many responses to open-ended, unstructured and multifaceted problems.

Divergent thinking provides the foundation for creative production, because it requires ideational searching without directional boundaries and is determined by fluency, flexibility and originality. However, ability to think divergently does not by itself produce creativity; critical thinking as well is needed
(Glassner \& Schwarz, 2007; Torrance, 1988). Some theorists propose "different sides of divergent thinking"; a generative and an evaluative side (e.g. Silvia, 2011: p. 29). It seems that individuals are likely to enhance their divergent thinking by, for example, training cognitive and neural mechanisms and engaging in improvisation (Gibson, Folley, \& Park, 2009). It is also known that older adults can think as divergently as young adults, but they do so at a slower rate and require more time than younger people (Foos \& Boone, 2008).

Bereiter and Scardamalia (2003) provide an interesting view of creativity. They propose two modes, a belief mode and a design mode, which characterize how people deal with knowledge in all kinds of contexts. In the belief mode, people deal with things that they believe or ought to believe; they agree or disagree with ideas, present arguments for or against, express and try to resolve doubts. Believing should incorporate critical thinking about beliefs, using evidence and logic and finding background knowledge in order to evaluate ideas.

In the design mode, people are concerned with the usefulness, adequacy, improvability and developmental potential of ideas. Design is not restricted only to creative products (e.g. crafts) but encompasses also conceptual artefacts, such as theories, proofs, problem formulations or interpretations. If we consider processes in which older people find ways to use technologies creatively, both modes are important. Creative thinking and creative use of technology go hand in hand. We argue there is a need to raise awareness of the creative potential of older adults in their use of ICT. Fozard (2001) considers the use of ICT for improving the elderly well-being under the concept "gerontechnology", arguing that it can delay and compensate for cognitive decline (e.g. using alert systems to improve temporal monitoring) and "enhance the quality of life and creativity of older people, and support family members and caregivers" (Fozard, 2001; Czaja, Charness, Fisk, \& Rogers, 2002: p. 2).

Before analyzing the specificities of the creative skills of older people and their creative use of ICT, we analyze creativity across the life span, including the evolution of the creative process from childhood to older age.

\section{Methodology for the Literature Review}

\section{Search Parameters}

Our search for relevant literature on creativity and collaboration among older adults began with identifying the main journals publishing in the creativity field and studies on older people and their use of ICT. We searched the journals Creative Education and Thinking Skills and Creativity using the terms "collaboration" and "ICT" to identify studies about collaborative creativity and the terms "elderly" or "aged". The Journal of Aging Studies was considered for studies on ageing and Gerontechnology: International Journal on the Fundamental Aspects of Technology to Serve the Ageing Society for studies relating to the use of ICT by the elderly. In both journals we searched with the terms "creativity" or "creative". Abstracts were scrutinised and potentially relevant articles obtained. A narrative synthesis of results is presented.

Creative Education and Thinking Skills and Creativity searches on the terms "collaboration" and "ICT" yielded 10 papers, whereas the searches on the terms "elderly", "aged”, "old" or "older" yielded one paper, which was not related to the study of creativity in elderly persons but to other subjects, 
among them one person working in elderly care. Searches in the Journal of Aging Studies on the terms "creativity" or "creative” yielded 44 papers of possible interest, and six additional papers were found in Gerontechnology.

\section{Results}

The studies described in the papers identified were found to fall into three areas of research. These were collaborative creative process; creativity in elderly; and finally, the collaborative creative process in the elderly. Considering creativity in general and the collaborative process in particular, we start the narrative synthesis by presenting the creative process across the life span, before focusing on the specific creative processes of the elderly.

\section{Collaborative Creative Process}

Creativity has been mainly studied as an individual process. In recent years, collaborative learning and teamwork in the workplace, in a context of increasing productivity, have highlighted the collaborative element in the creative process. Studies have considered creativity as a collaborative and situated process (Fernández-Cárdenas, 2008; Eteläpelto \& Lahti, 2008). According to Eteläpelto and Lahti (2008), different characteristics of group settings can influence the collaborative creative process, such as the emotional atmosphere and the power relations between the members of the group. Among Finnish teacher trainees, a negative, unsafe atmosphere made group members afraid of being emotionally hurt. On the other hand, complementary discussions, utilisation of others' views, a shared history among the group, rich emotional scaffolding and the tutor's support enhanced creative collaboration. The emotional dimension seems a particularly important element of creative collaboration.

Creativity in educational contexts has recently been studied widely within the 27 member states of the European Union. According to one survey (Ferrari, Cachia, \& Punie, 2010), a majority of teachers believe that "creativity can be applied to every domain of knowledge (98\%) and to every school subject (96\%)". However, the place of creativity in the national curriculum varies from one country to another (Cachia et al., 2009). Kampylis, Berki and Saariluoma (2009) studied Greek teachers' (in service and pre-service) conceptions about creativity, and found that most of them belonged to a "school-sceptic" group and believed that creativity exists only in traditional subjects such as theatre, arts and music but is a key component in personal and social progress. However, it seems that creativity as a concept is neither adequately understood nor supported among the teachers.

\section{The Creative Process across the Life Span}

Age and educational level are considered to be important variables in the development of cognitive maturity (King \& Kitchener, 1994; Perry, 1970). According to Perry, students in their early to mid-20s have not fully reached the higher levels of cognitive maturity that allow them to engage in reflective thinking. King and Kitchener's Reflective Judgment Model considers seven stages in cognitive developmental progression in reasoning, which represent "distinct sets of assumptions about knowledge and how knowledge is acquired" (p. 13). Their research showed that reflective judgment scores increased consistently with age and educational level. The increase of creativity among adults, including older adults, is also defended by Cohen (2000), who argues for considering the opportunities for creativity in the second half of life.

For some authors, children are naturally creative and open to experience and novelty; but this human potential has to be developed in order to be maintained in the later stages of life (Esquivel, 1995; Feldman \& Benjamin, 2006; Lin, 2011). In the early years, according to Clay (2001), writing is an important means of stimulating children's creative thinking. Chen and Zhou (2010) consider the creative process in children aged from five to six years in a writing task. They observe the positive impact of providing the children with an open-ended task, allowing them to use pictures to represent the meanings of the characters they are writing about.

In the psychology of development literature, adolescence and young adulthood are considered the optimal stage for the development of higher order cognitive processes. For Giedd and colleagues (1999), cognitive skills are better developed in adolescence than in childhood. Despite this possible advantage, Marin and Halpern (2011) observe the beneficial effect of direct instruction to obtain higher performance in the Halpern Critical Thinking Assessment (Halpern, 1998) among low-income high students in America. Robbins and Kegley (2010) consider the development of creativity abilities among 51 students participating in a Principles of Management course $(\mathrm{N}=25)$ or a Creative Inquiry free elective course $(\mathrm{N}=26)$. Data was collected using the Torrance Tests of Creative Thinking (TTCT, Torrance, 1988) pre- and post-testing. Results revealed a significant increase in the participants' creative self-efficacy in the Creative Inquiry course, which aimed to develop the students' creativity in a direct way.

Fischer and Nakakoji (1997) consider creativity among adults in everyday life, focusing their study on the world of professional designers in a collaborative learning environment for facilitating creativity in the workplace by the sharing of ideas. Information sharing is one of the key elements for promoting collaborative creativity among the team to reach a common objective. WyattBrown (1989) analyses a case of creativity, namely that of the novelist Anita Brookner. Wyatt-Brown analyses Brookner's novels and interviews her in her fifties to consider the evolution of creativity in advanced adulthood, particularly in order to counter the passivity of accepting the direction of her midlife.

\section{Older Adults' Profile and Their Creativity}

In this section, we focus on the specificities of the elderly target group and their creative capabilities, before introducing specific ways in which their creativity may be enhanced.

Older adults are defined in many ways, depending on which area of aging is under study. In studies relating to the working life, a 45-year-old can be classified as an older adult, whereas in the context of ICT, the designation "older adults" may refer variably to those between 40 years and 75 years. In research relating specifically to successful ageing and creativity in later life, the limit extends to 93 years (Fisher \& Spech, 1999). Older adults are not a homogeneous group but are heterogeneous individuals with many differences.

Life expectancy is increasing in the world's richest nations, which translates into an increased emphasis on the physical, cognitive and emotional needs of the growing numbers of older adults. Although there exist different approaches to late adulthood in developmental psychology (Havighurst, 1972), the gen- 
eral characteristics of this vital stage are driven by the last permanent changes in cognitive, sensory-motor and social competencies.

Although older adults have not been the subject of extensive study to date, at least three different theoretical perspectives can be distinguished.

1) First, we may consider theories about normative crisis. All these theories are basically descriptive and rely on age-related sequences in the human life span structured by developmental phase. Relevant theories are the "eight ages" of Erikson (1950, 1968), Piaget’s "genetic epistemology” $(1977,1985)$ or Baltes's vital cycles (1990).

2) Second, we can identify theories about successful aging. These models are not based on developmental deficits like the previous ones but driven by a satisfactory construct of life. They describe ways and processes to arrive at a high level of personal satisfaction by adapting to change (Baltes \& Baltes, 1989; Fisher \& Spech, 1999; Havighurst \& Taba, 1949).

3) Third, there are specific or partial theories. This approach does not explain psychosocial aging process as a whole but is precisely focused on the period of older adulthood, and the theories involved mainly deal with cognitive achievement and sensory functions (Lindenberger \& Baltes, 1994); socio-emotional selectivity (Carstensen, 1992) and developmental contextualism based on changing co-actions between the individual and his/her context (Lerner, 2002).

All these perspectives agree that late adulthood is a period of adaptation to new personal resources, which leads to a paradox: the individual apparently experiences a progressive decline in activity and is subject to greater physical and cognitive limits but at the same time is better able to adapt to it. This so-called "practical intelligence" or wisdom can be understood as expert knowledge about vital questions (Staudinger \& Baltes, 1996) and enables the elderly to sort out conflicts that youth and more efficient decision-making processes struggle with, as they are better able to grasp the consequences of situations and to establish clear priorities. Older adults thus seem better equipped to solve creatively situations in which they are more experienced, but experience specific challenges in the context of the use of ICT, where they manifest more than twice as many user difficulties as younger users (Nielsen, 2002) and feel less confident about their own computer knowledge (Marquié, Jourdan-Boddaerta \& Huet, 2002). Despite their lower confidence levels, most healthy seniors are very well capable of acquiring computer skills (Mayhorn, Lanzolla, Wogalter, \& Watson, 2005; Morrell, 2002), especially with specific training (Temple \& Gavillet, 1990). Their use of the technology is based on a more reflective and utilitarian approach, rather than trial-and-error strategies, leading to different uses of ICT (Docampo Rama, 2001). Moreover, they consider the utility of ICT before they adopt the technology, in particular communication technology as a means of compensating for their mobility difficulties (Melenhorst, 2002).

\section{Enhancing Creativity in Older Adults}

Despite the decline of certain cognitive and sensory functions in the elderly (Linderberger \& Baltes, 1994), their enhanced "practical intelligence" helps in decision-making and can promote certain forms of creativity. According to King and Kitchener (1994), elderly and better educated subjects score more highly in tests of judgement, which has implications for study of the evolution of creativity and critical thinking skills across the life span from a developmental perspective, as well as of the specific development of these competencies through training.

Critical thinking and creativity are considered throughout the life span as a competency that can be enhanced by specific training. For this reason, creativity has been included in educational policy and the education curriculum in different countries (Shaheen, 2010). However, most of the work carried out in the development of critical thinking skills has been done in face-to-face contexts. In the context of online learning, Muirhead (2004) also notes that specific course materials and activities may be developed to enhance online learners' reflective skills. Bullen's research (1998) considers the relation between participation and creativity in online discussions, observing the influence of four major factors: cognitive maturity, teaching style of the instructor, students' prior learning experiences and degree of understanding of the critical thinking process. The online teacher's role is to help eliminate myths about creativity with a view to developing the potential of the online learners.

The relationship between successful aging and creative activity is studied by Fisher and Specht (1999). The results indicate that successful aging comprises six features, namely a sense of purpose, interaction with others, personal growth, self-acceptance, autonomy and health. Creative activity fosters a sense of competence, purpose and growth and hence contributes to successful aging. Recent studies, however, show that some older adults deliberately reject the use of computers, preferring to pursue other activities such as handicrafts and use of other audiovisual media (Hakkarainen \& Hyvönen, 2010).

\section{Conclusion}

Considering the specificities of elderly persons and opportunities for enhancing creativity with the use of ICT, we aim to highlight three major aspects that may be taken into account in the design of computer-supported collaborative creativity spaces for use by the elderly. First, the ergonomy of the ICT should reflect the decline of sensory capacities among the elderly in the design of interfaces. Second, in respect of the reflective process of the elderly, we propose computer-supported collaborative creative spaces where guidance focuses clearly on reducing trial-and-error in the process of understanding. Third, the computer-supported collaborative creative spaces should make explicit the utility of ICT in the creative process in order to increase its acceptability among the elderly. Finally, we should consider the value to the elderly of technology for communication when they face mobility problems. In this case, computer-supported spaces may help to solve everyday life challenges and bring part of the community to the elderly person.

\section{Acknowledgements}

This study is developed within the CoCreat project that has been funded with support from the European Commission (LifeLong Learning Programme). This publication reflects the views only of the author, and the Commission cannot be held responsible for any use, which may be made of the information contained therein. The CoCreat partners involved in this study belongs to University of Oulu (Finland) and Universitat Oberta de Catalunya (Spain). 


\section{REFERENCES}

Ala-Mutka, K., Punie, Y., \& Redecker, C. (2008). Digital competence for lifelong learning. Luxemburg: Office for Official Publications of the European Communities.

Amabile, T. M. (1996). Creativity in context. Boulder, CO: Westview Press.

Baltes, P. B. (1990). Life-span developmental-psychology—Basic theoretical principles. Psychologische Rundschau, 41, 1-24.

Baltes, P. B., \& Baltes, M. M. (1989). Selective optimizacion with compensation-A psychological model of successful aging. Zeitschrift für Pädagogik, 35, 85-105.

Bereiter, C., \& Scardamalia, M. (2003). Learning to work creatively with knowledge. In E. D. Corte, L. Vershaffel, N. Entwistle, \& J. van Merriënboer (Eds.), Unravelling basic components and dimensions of powerful learning environments (pp. 55-68). Pergamon: European Association for Research on Learning and Instruction.

Bullen, M. (1998). Participation and critical thinking in online university distance education. Journal of Distance Education, 13, 1-32.

Cachia, R., Ferrari, A., Kearney, C., Punie, Y., Van den Berghe, W., \& Wastiau, P. (2009). Creativity in schools in Europe: A survey of teachers. IPTC Publications.

http://ipts.jrc.ec.europa.eu/publications/pub.cfm?id=2940

Capdeferro, N., \& Romero, M. (2012). Are online learners frustrated with collaborative learning experiences? The International Review of Research in Open and Distance Learning, 13, 26-44.

Carstensen, L. L. (1992). Social and emotional patterns in adulthood: Support for socioemotional selectivity theory. Psychology and Aging, 7, 331-338. doi:10.1037/0882-7974.7.3.331

Charness, N., \& Holley, P. (2004). The new media and older adults. American Behavioral Scientist, 48, 416-433. doi:10.1177/0002764204270279

Charness, N., Czaja S., Fisk, A. D. \& Rogers, W. A. (2002). Creative use of technology for better aging. Gerontechnology, 2, 1-166.

Chen, S. \& Zhou, J. (2010). Creative writing strategies of young children: Evidence from a study of Chinese emergent writing. Thinking Skills and Creativity, 5, 138-149. doi:10.1016/j.tsc.2010.09.002

Clay, M. M. (2001). Change over time in children's literacy development. Portsmouth, NH: Heinemann.

Cody, M. J., Dunn, D., Hopkins, S., \& Wendt, P. (1999). Silver surfers: Training and evaluating Internet users among older adult learners. Communication Education, 48, 269-286. doi:10.1080/03634529909379178

Cohen, G. D. (2000). The creative age: Awakening human potential in the second half of life. New York: Avon Books.

Craig, C. L. (2010). Creativity and communication: Making use of everyday technology in care homes. Gerontechnology, 9, 277. doi:10.4017/gt.2010.09.02.176.00

Csikszentmihalyi, M. (1997). Creativity: Flow and the psychology of discovery and invention. New York: Harper Collins.

Czaja, S. J., Charness, N., Fisk, A. D., \& Rogers, W. (2002). Welcome to gerontechnology 2002: Creative use of technology for better aging. Gerontechnology, 2, 1-2. doi:10.4017/gt.2002.02.01.001.00

Dillenbourg, P. (2005). Designing biases that augment socio-cognitive interactions. In R. Bromme, F. W. Hesse, \& H. Spada (Eds.), Barriers and biases in computer-mediated knowledge communication and how they may be overcome (pp. 243-264). New York: Springer. doi:10.1007/0-387-24319-4_11

Dillenbourg, P., Baker, M., Blaye, A., \& O’Malley, C. (1996). The evolution of research on collaborative learning. In P. Reimann, \& H. Spada (Eds). Learning in humans and machines. Towards an interdisciplinary learning science (pp. 189-211). London: Pergamon.

Dillenbourg, P., Järvelä, S., \& Fischer, F. (2009). The evolution of research on computer-supported collaborative learning: From design to orchestration. In N. Balacheff, S. Ludvigsen, T. de Jong, T. A. Lazonder, \& S. Barnes (Eds.), Technology-enhanced learning: Principles and products (pp. 3-19). New York: Springer.

Docampo Rama, M. (2001). Technology generations handling complex user interfaces. Ph.D. Dissertation, Eindhoven: Eindhoven University of Technology.

Erikson, E. (1950). Childhood and society. New York: Vintage.
Erikson, E. (1968). Identity: Youth and crisis. New York: W. W. Norton \& Company.

Esquivel, G. B. (1995). Teacher behaviours that foster creativity. Educational Psychology Review, 7, 185-201. doi:10.1007/BF02212493

Eteläpelto, A. \& Lahti, J. (2008). The resources and obstacles of creative collaboration in a long-term learning community. Thinking Skills and Creativity, 3, 226-240. doi:10.1016/j.tsc.2008.09.003

Eysenck, H. J. (1995). Genius: The natural history of creativity. Cambridge: Cambridge University Press. doi:10.1017/CBO9780511752247

Feldman, D. H., \& Benjamin, A. C. (2006). Creativity and education: An American retrospective. Cambridge Journal of Education, 36, 319-336. doi:10.1080/03057640600865819

Fernández-Cárdenas, J. M. (2008). The situated aspect of creativity in communicative events: How do children design webpages together? Thinking Skills and Creativity, 3, 203-216. doi:10.1016/j.tsc.2008.09.007

Ferrari A., Cachia R., \& Punie Y. (2010). Expert perspectives on creativity and innovation in European schools and teacher training. Séville: Joint Research Centre-Institute for Prospective Technological Studies, JRC Technical Notes, No. EUR JRC 59833.

Fischer, G., \& K. Nakakoji (1997). Computational environments supporting creativity in the context of lifelong learning and design. Knowledge Based Systems, 10, 21-28. doi:10.1016/S0950-7051(97)00010-5

Fisher, B. J., \& Specht, D. K. (1999). Successful aging and creativity in later life. Journal of Aging Studies, 33, 457-472. doi:10.1016/S0890-4065(99)00021-3

Fozard, J. L. (2001). Gerontechnology and perceptual-motor function new opportunities for prevention, compensation and enhancement. Gerontechnology, 1, 5-24. doi:10.4017/gt.2001.01.01.002.00

Foos, P. W., \& Boone, D. (2008). Adult age differences in divergent thinking: It's just a matter of time. Educational Gerontology, 34, 587-594. doi:10.1080/03601270801949393

Fozard, J. L., Bouma, H., Franco, A., \& Bronswijk, J. E. M. H. (2009). Homo ludens: Adult creativity and quality of life. Gerontechnology, 8, 187-196. doi:10.4017/gt.2009.08.04.001.00

Franken, R. (1994). Human motivation. Pacific Grove, CA: Brooks/Cole. Frydenberg, M. E., Andone, D. (2011). Learning for 21st Century Skills. IEEE's International Conference on Information Society, London, 27-29 June 2011, 314-318.

Galusha, J. M. (1998). Principles of training and of adult education: A comparison. Hattiesburg, MS: University of Southern Mississippi.

Gibson, C., Folley, B. S., \& Park, S. (2009). Enhanced divergent thinking in musicians: A behavioural and near-infrared spectroscopy study. Brain and Cognition, 69, 162-169. doi:10.1016/j.bandc.2008.07.009

Giedd, J. N., Blumenthal, J., Jeffries, N. O., Castellanos, F. X., Liu, H., Zijdenbos, A., Paus, T., Evans, A. C., \& Rapoport, J. L. (1999). Brain development during childhood and adolescence: A longitudinal MRI study. Nature Neuroscience, 2, 861-863. doi:10.1038/13158

Glassner, A. \& Schwarz, B. B. (2007). What stands and develops between creative and critical thinking? Thinking Skills and Creativity, 2, 10-18. doi:10.1016/j.tsc.2006.10.001

Guilford, J. P. (1959). Personality. New York: McGraw-Hill.

Guilford, J. P. (1962). Factors that aid and hinder creativity. Teachers College Record, 63, 380-392.

Hadwin, A. F., Oshige, M., Gress, C. L. Z., \& Winne, P. H. (2010) Innovative ways for using gStudy to orchestrate and research social aspects of self-regulated learning. Computers in Human Behavior, 26, 794-805. doi:10.1016/j.chb.2007.06.007

Hakkarainen, P. (2012). "No good for shovelling snow and carrying firewood": Social representations of computers and the internet by elderly Finnish non-users. New Media and Society, 1-18. doi:10.1177/1461444812442663

Hakkarainen, P., \&, Hyvönen, P. (2010). Tietokoneeton elämä yli 60-vuotiaan valintana-Tunteita ja perusteluja [Over 60 years old person's deliberate choice of computerless life: Emotions and justifications]. Media \& Viestintä, 4, 79-96.

Halpern, D. F. (1998). Teaching critical thinking for transfer across domains: Dispositions, skills, structure training, andmetacognitive monitoring. American Psychologists, 53, 449-455. 
doi:10.1037/0003-066X.53.4.449

Havighurst, R., \& Taba, H. (1949). Adolescent character and personality. New York: John Wiley \&Sons.

Havighurst, R. J. (1972). Developmental tasks and education. New York: David McKay.

Hilton, M. (2008). Skills for work in the 21st century: What does the research tell us? Academy of Management Perspectives, 22, 63-78. doi:10.5465/AMP.2008.35590354

Hyvönen, P. (2002). Tietoverkot ikääntyneen oppijan voimaantumisprosessissa [The meaning of networks for empowering older adults]. Rovaniemi: University of Lapland.

Hyvönen, P., Romero, M., \& Barbera, E. (2012). Technology-enhanced learning for creative collaboration in older adults. Proceedings of the 2012 EDEN Annual Conference, Porto, June 2012.

Järvelä, S., Volet, S., \& Järvenoja, H. (2005). Motivation in collaborative learning: New concepts and methods for studying social processes of motivation. A paper presented at the EARLI 2005 conference, 22-27 August 2005, Nicosia, Cyprus.

Kampylis, P., Berki, E., \& Saariluoma, P. (2009). In-service and prospective teachers' conceptions of creativity. Thinking Skills and Creativity, 4, 15-29. doi:10.1016/j.tsc.2008.10.001

King, P. M. \& Kitchener, K. S. (1994). The development of reflective judgment in adolescence and adulthood. San Francisco, CA: Jossey Bass.

Lambropoulos, N., Romero, M., \& Kommers, P. (2011). Special issue on community-based innovation: Designing shared spaces for collaborative creativity. International Journal of Web Based Communities, 7, 403-406.

Lerner, R. M. (2002). Concepts and theories of human development (3rd ed.). Hillsdale, NJ: Lawrence Erlbaum.

Lin, Y.-S. (2011). Fostering creativity through education-A conceptual framework of creative pedagogy. Creative Education, 2, 149155.

Lindenberger, U., \& Baltes, P. B. (1994). Sensory functioning and intelligence in old age: A strong connection. Psychology and Aging, 9, 339-355. doi:10.1037/0882-7974.9.3.339

Malecki, E. J. (2003). Digital development in rural areas: Potentials and pitfalls. Journal of Rural Studies, 19, 201-214. doi:10.1016/S0743-0167(02)00068-2

Marin, L., \& Halpern, D. F. (2010). Pedagogy for developing critical thinking in adolescents: Explicit instruction produces greatest gains. Thinking Skills and Creativity, 6, 1-13. doi:10.1016/j.tsc.2010.08.002

Marquié, J. C., Jourdan-Boddaert, L., \& Huet, N. (2002). Do older adults underestimate their actual computer knowledge? Behaviour \& Information Technology, 21, 273-280.

doi:10.1080/0144929021000020998

Mayhorn, C. B., Lanzolla, V. R., Wogalter, M. S., \& Watson, A. M. (2005). Personal digital assistants (PDAs) as medication reminding tools: Exploring age differences in usability. Gerontechnology, 4, 128-140. doi:10.4017/gt.2005.04.03.003.00

Melenhorst, A.-S. (2002). Adopting communication technology in later life. The decisive role of benefits. Ph.D. Dissertation, Eindhoven: Eindhoven University of Technology.

Morrell, R. W. (2002). Older adults, health information and the World Wide Web. Mahwah, NJ: Lawrence Erlbaum Associates.

Muirhead, B. (2004). Editorial: Online education: Innovative \& personal. International Journal of Instructional Technology and Distance Learning, 1, 1-2.

Nielsen, J. (2002). Usability for senior citizens. URL (last checked 30 April 2011). http://www.useit.com/alertbox/20020428.html

Perry, W. G. (1970). Forms of intellectual and ethical development in the college years: A scheme. New York: Holt, Rinehart \& Winston.

Piaget, J. (1977). The grasp of consciousness: Action and concept in the young child. London: Routledge and Kegan Paul.

Piaget, J. (1985). The equilibration of cognitive structures: The central problem of intellectual development. Chicago: University of Chicago Press. (New translation of the development of thought) child's conception of geometry.

Plucker, J., Beghetto, R., \& Dow, G. (2004). Why isn't creativity more important to educational psychologists? Potentials, pitfalls, and future directions in creativity research. Educational Psychologist, 39,
83-96. doi:10.1207/s15326985ep3902_1

Robbins, T. L., \& Kegley, K. (2010). Playing with thinkertoys to build creative abilities through online instruction. Thinking Skills and Creativity, 5, 40-48. doi:10.1016/j.tsc.2009.07.001

Rojanapanich, P., \& Pimpa, N. (2011). Creative education, globalization and social imaginary: A case of higher education. Creative Education, 2, 327-332. doi:10.4236/ce.2011.24046

Romero, M., \& Barberà, E. (2012). Creative collaboration continuum enhanced by online education: Time pressure, time quality and social interaction. 34th IATUR Conference on Time Use Research, Matsue, 22-24 August 2012.

Roschelle, J., \& Teasley, S. (1995). The construction of shared knowledge in collaborative problem solving. In O’Malley, C. E. (ed.), Computer Supported Collaborative Learning (pp. 69-97). Heidelberg: Springer-Verlag.

Runco, M. A. (2007). Creativity: Theories and themes: Research, development, and practice. Amsterdam: Elsevier Academic Press.

Sak, U., \& Oz, O. (2010). The effectiveness of the Creative Reversal Act (CREACT) on students' creative thinking. Thinking Skills and Creativity, 5, 33-39. doi:10.1016/j.tsc.2009.09.004

Scardamalia, M. (2003). Crossing the digital divide: Literacy as by-product of knowledge building. Journal of Distance Education, 17, 78-81.

Scardamalia, M., \& Bereiter, C. (1994). Computer support for knowledge-building communities. The Journal of the Learning Sciences, 3, 265-283. doi:10.1207/s15327809jls0303_3

Selwyn, N. (2004). The information aged: A qualitative study of older adults' use of information and communications technology. Journal of Aging Studies, 18, 369-384. doi:10.1016/j.jaging.2004.06.008

Selwyn, N., Gorard, S., \& Furlong, J. (2005). Adult learning in a digital age. London: Routledge/Falmer.

Selwyn, N., Gorard, S., \& Furlong, J. (2005). Whose Internet is it anyway? Exploring adults' (non)use of the internet in everyday life. European Journal of Communication, 20, 5-26. doi:10.1177/0267323105049631

Shaheen, R. (2010). Creativity and education. Creative Education, 1, 166-169. doi:10.4236/ce.2010.13026

Silvia, P. J. (2011). Subjective scoring of divergent thinking: Examining the reliability of unusual uses, instances, and consequences tasks. Thinking Skills and Creativity, 6, 24-30.

doi:10.1016/j.tsc.2010.06.001

Sourbati, M. (2009). "It could be useful, but not for me at the moment": Older people, Internet access and e-public service provision. New Media \& Society, 11, 1083-1100. doi:10.1177/1461444809340786

Staudinger, U. M., \& Baltes, P. B. (1996). Interactive minds: A facilitative setting for wisdom-related performance? Journal of Personality and Social Psychology, 71, 746-762.

doi:10.1037/0022-3514.71.4.746

Sternberg, R. J., \& Lubart, T. I. (1995). Defying the crowd: Cultivating creativity in a culture of conformity. New York: Free Press.

Straker, D. \& Rawlinson, G. (2003). How to invent (almost) anything. London: Spiro Press.

Sundholm, H., Artman, H., \& Ramberg, R. (2004). Backdoor creativity: Collaborative creativity in technology supported teams. In F. Darses, R. Dieng, C. Simone, \& M. Zacklad (Eds.), Cooperative systems design: Scenario-based design of collaborative systems (pp. 99-114). Amsterdam: IOS press.

Temple, L. L., \& Gavillet, M. (1990). The development of computer confidence in seniors: An assessment of changes in computer anxiety and computer literacy. Activities, Adaptation, and Aging, 14, 63-76. doi:10.1300/J016v14n03 06

Torrance, E. P. (1988). Style of learning and thinking: Administrator's manual. Bensenville, IL: Scholastic Testing Service.

Trilling, B., \& Fadel, C. (2009). 21st century skills: Learning for life in our times. San Francisco, CA: Jossey-Bass.

Vuori, S., \& Holmlund-Rytkönen, M. (2005). 55+ people as Internet users. Marketing Intelligence \& Planning, 23, 58-76. doi:10.1108/02634500510577474

Wagner, N., Hassanein, K., \& Head, M. (2010). Computer use by older adults: A multi-disciplinary review. Computers in Human Behavior, 26, 870-882. doi:10.1016/j.chb.2010.03.029 
M. ROMERO ET AL.

Wyatt-Brown, A. M. (1988). Late style in the novels of Barbara Pym and Penelope Mortimer. The Gerontologist, 28, 835-839. 